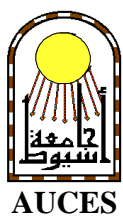

\title{
RESIDUAL EFFECT OF HEAVY METALS DUE TO USED DRINKING WATER POLLUTED WITH SEWAGE ON HEALTH PERFORMANCE AND BLOOD SERUM ANTIOXIDANT VITAMINS IN SHEEP AND GOATS IN ASSIUT GOVERNORATE
}

\author{
Abd El-Rahman Ahmed Ali \\ Dept. of Biochemistry, Assiut Health Research Institute, Assiut.
}

\begin{abstract}
:
The present work was directed to detect the residues of heavy metals in some water canals in which the sewage waste water was discharged in some villages of Assiut Governorate. In addition this research was planned to study the effect the use of such water on the health performance and blood serum antioxidant vitamins (vitamin A, Beta Carotene, vitamin E and vitamin C) of sheep and goats drinking from these water sources. The obtained results were compared with of those sheep and goats drinking from tap water.
\end{abstract}

A total number of 115 sheep of both sexes and 80 goats of both sexes aged from 3-5 years belonged to some owners in some villages at Assiut Governorate, these animals are drinking water polluted with sewage for long period. Besides, a total number of 25 sheep of both sexes and 25 goats of both sexes aged from 3-5 years drinking form tap water for long periods in the same villages used as control. Blood samples were collected to obtain clear sera for estimation of vitamin A, Beta carotene, vitamin $\mathrm{E}$ and vitamin $\mathrm{C}$.

20 water samples were collected from water canals polluted with sewage, in addition to 10 tap water samples from the same villages. Chemical analysis of water samples was carried out to estimate lead, cadmium, copper and zinc concentrations using Atomic Absorption Spectrophotometer. The obtained data revealed that lead, cadmium, copper and zinc concentrations in water samples of canals polluted with sewage were highly significantly elevated than the international permissible limits and also significantly increased than those of tap water. The biochemical analysis of blood serum showed a highly significant decrease in the levels of vitamin A, Beta carotene, vitamin $E$ and vitamin $C$ in the serum of both sheep and goats drinking from polluted water compared with those drinking from tap water.

The health condition of sheep and goats drinking water form canals polluted with sewage was clearly lowered which was manifested by abnormal activity, emaciation, weakness, debility, depression and the anemic changes especially pale mucous membranes.

It could be concluded that heavy metal pollution problems in the studied water canals were serious as reflected by the high concentration in lead, cadmium, copper and zinc levels in the collected water samples. Therefore preventive measures must be intended to minimize the pollution of water. Hygienic disposal of sewage must also be applied. Education of the farmers and the owners of sheep and goats about the risk of such pollutants should, also, be applied. 


\section{INTRODUCTION:}

Water pollution became one of the major problem facing public health. Steadily increasing flow of pollutants is discharged into natural water form different sources. Toxic contaminants of water may directly produce their harmful effect or it may be indirectly predispose animals to infections by lowering immune status (Koller, 1979 and Dean et al 1986).

Water supply systems for human and animals in Egypt are constructed in response to the goal of drinking water by different ways, where sometimes, directly form the River Nile or its branches including the present canals whether irrigation or drainage ones, in addition to healthy sanitary water supplies especially from tap water (El - Marazky, 1988).

The improper disposal of the untreated sewage water can pose pollution of water and soil and consequently affect the biosystem and human health adversely (Omer et al., 2004) Generally, sewage waste water contains many types of pollutants, the greatest threats arise from heavy metals, trace elements, and many toxic chemicals as well as different types of pathogens (Lake et al., 1984; Dean and Suess, 1985 and Blumenthal et al., 2001).

Concerning the water resources for animals drinking in certain villages, some drainage and irrigation canals have certain interest due to the high concentration of heavy metals and trace elements in their water (El-Marozky, 1988 and Omer et al., 2004).

Heavy metals and other trace elements have been considered as dangerous substances causing serious health hazards to human, animals and other living organisms, through progressive irreversible accumulation in their bodies as a result of repeated consumption of small amounts of these elements (Wheaton and Lawson, 1985; Clark, 1989 and Goel, 1997).
Inside the animal body, there are several types of defense mechanisms, among these defense mechanisms come antioxidant vitamins defense such as vitamin $A$, Beta carotene, vitamin E and vitamin C (Joan et al., 1995 and Rock et al., 1996). Furthermore, these low molecular weight antioxidant vitamins are capable of scavenging the harmful effect of free radicals and other highly reactive species which are capable of damaging DNA, protein, carbohydrates and fats (Lynch et al., 1999).

Nowadays, it is difficult to open a medical journal without seeing some paper on the role of free radicals in human and animal diseases and the possible protective mechanisms against them by using antioxidants (Rock et al., 1996). Each of the antioxidant vitamins has specific characteristics and often they work synergistically to strengthen the overall antioxidant capability of the body. For instance vitamin $E$ is now recognized as an important biologic antioxidant vitamin acting against the adverse effect of reactive oxygen and free radicals as well as it is associated with improved immune response (Rammel, 1983; Stephen et al., 1989 and Macpherson, 1994).

Vitamin A was recognized to have substantial immunostimulatory properties and by that to affect considerably host defense systems. Particularly, vitamin A increases lymphocyte proliferation, stimulates delay hypersensenstivity, increases killer cells activity and improves macrophage and neutrophil, function (Muneer et al., 1988 and Kaneko et al., 1997). Beta carotene, has many of the same activities because it can be converted into vitamin A (Chew, 1987). Yet certain immunoostimulatory effects of Beta carotene are supposed to be independent from its provitamin A function.

Vitamin $\mathrm{C}$ has a pronounced antioxidant activity. Most vertebrates are able to synthesize 
ascorbic acid, although endogenous production does not always meet the requirements of farm animals under exceptional conditions such as stress (Gilbert, 1997). Vitamin C whether intracellular or extracellular directly reduce the present free radicals with formation of dehydroscorbate (Kaneko et al., 1997). Vitamin $\mathrm{C}$, also, enhances the individual animal resistance against infectious agents and stress factors affecting the animal by improving the immune function of the animal body (Cummins and Brunner, 1991 and Fenster and Weiser, 1994).

The aim of the present study is to estimate the concentrations of heavy metals lead, cadmium, copper and zinc in the water of some water canals polluted with sewage waste water in comparison with the concentrations of these metals in the tap water in some villages of Assiut Governorate. In addition, this investigation was planned to study the effect of this polluted water with sewage on the health performance and blood serum antioxidant vitamins of sheep and goats drinking from this polluted water and compare with those drinking from tap water.

\section{MATERIALS AND METHODS:}

\section{Animals:}

This investigation was carried out on 115 adult sheep of both sexes and 80 adult goats of both sexes aging from 3-5 years old, these animals drinking water from water canals polluted with sewage waste water for long periods. These animals belonging to a private farms, the owners of these animals continuously drinking their animals from these canals in different villages of Assiut Governorate. In addition 25 sheep of both sexes and 25 goats of both sexes aging from 3-5 years old drinking from tap water continuously at the same villages were used as control. All animals were subjected to careful clinical and laboratory investigation to insure their healthy condition according to Pugh (2002).

All animals used in this study were free from internal and external parasites after laboratory examinations.

\section{Samples and adopted methods :}

1-Water samples: 20 water samples from water canals polluted with sewage waste water, and 10 from tap water were collected from the same villages. Water samples were collected in clean glass bottles for chemical analysis according to APHA (1995) and Kegley et al (1998).

Qualitative determination of lead, cadmium, copper and zinc were carried out using Atomic Absorption Spectrophotometer (Perkin Elmer 2380, U.S.A).

2-Blood samples: were collected from the jugular vein in dry metal free centrifuge tube and left to clot at room temperature, then centrifuged at 3000 r.p.m for 10 minutes to separate the serum. The collected clear sera were kept at $-20^{\circ} \mathrm{C}$ till used for biochemical analysis.

Blood serum vitamin A and Beta carotene were determined Spectrophotometrically according to Carr and Price (1926). Blood serum vitamin $\mathbf{E}$ was determined Spectrophotometrically after Hawks et al. (1954). Blood serum vitamin $C$ was determined Spectrophoto-metrically according to Lowery $e t$ al. (1945).

\section{Statistical analysis :}

The obtained data were subjected to software program according to Selvin (1996). 


\section{RESULTS:}

The health performance of sheep and goats drinking from fresh tap water and those drinking from polluted water with sewage are illustrated in table (1). The results of chemical analysis of both tap water and water polluted with sewage were recorded in table (2). Biochemical analysis of blood sera for antioxidant vitamins in sheep and goats drinking fresh tap water and those drinking water polluted with sewage were presented in tables ( 3 \& 4).

Table (1): Health performance of sheep and goats drinking for fresh tap water and water polluted with sewage.

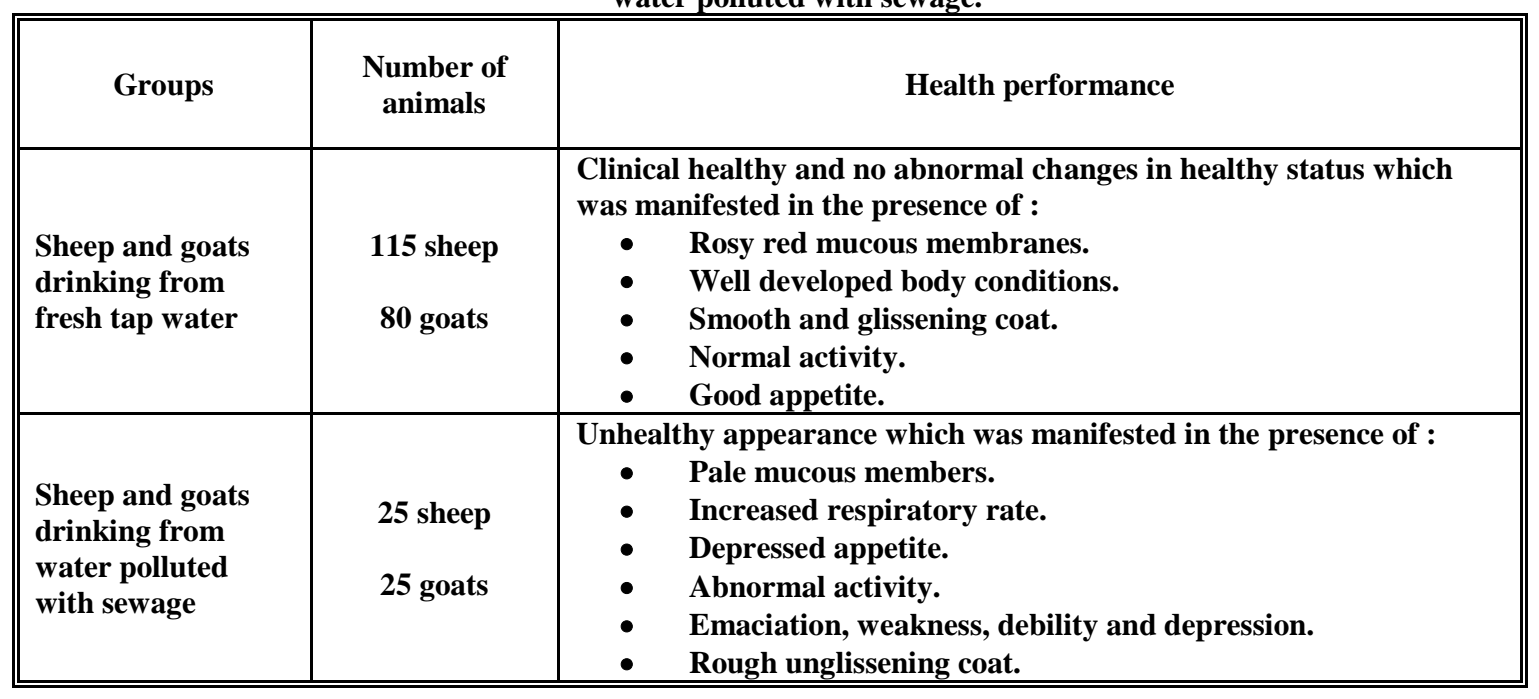

Table (2): Concentrations (p.p.m) of heavy metals in fresh tap water and polluted canal water with sewage.

\begin{tabular}{||c|c|c|c||}
\hline \multirow{2}{*}{ Heavy metals } & $\begin{array}{c}\text { Fresh tap water } \\
\bar{X} \pm \mathrm{SD}\end{array}$ & $\begin{array}{c}\text { Polluted canal water } \\
-\end{array}$ & $\begin{array}{c}\text { Permissible limit of metals in water (ppm) } \\
\text { (WHO 1964) }\end{array}$ \\
\hline Lead $(\mathbf{P b})$ & $\mathbf{0 . 2 2 8} \pm \mathbf{0 . 0 . 0 5 7}$ & $\mathbf{X} \pm \mathrm{SD}$ & $\mathbf{0 . 0 5}$ \\
Cadmium $(\mathrm{Cd})$ & $\mathbf{0 . 0 0 4} \pm \mathbf{0 . 0 0 1}$ & $\mathbf{0 . 6 3 7} \pm \mathbf{0 . 0 2 3} * *$ & $\mathbf{0 . 0 0 5}$ \\
Copper $(\mathrm{Cu})$ & $\mathbf{0 . 6 7 9} \pm \mathbf{0 . 0 5 8}$ & $\mathbf{5 . 2 6 0}+\mathbf{0 . 6 7 7 * *}$ & $\mathbf{1 . 0 0 0}$ \\
Zinc $(\mathrm{Zn})$ & $\mathbf{2 . 8 4 5} \pm \mathbf{0 . 2 4 0}$ & $\mathbf{9 . 2 8 9} \pm 1.980 * *$ & 5.000 \\
\hline
\end{tabular}

Table (3): Blood serum levels of antioxidant vitamins in sheep drinking from fresh tap water and those drinking from polluted canal water

\begin{tabular}{|c|c|c|c|c|c|}
\hline Animals & Statistics & $\begin{array}{c}\text { Beta-carotene } \\
\mathrm{mg} / 100 \mathrm{ml}\end{array}$ & $\begin{array}{l}\text { Vitamin A } \\
\mu \mathrm{g} / 100 \mathrm{ml}\end{array}$ & $\begin{array}{l}\text { Vitamin E } \\
\mu \mathrm{g} / 100 \mathrm{ml}\end{array}$ & $\begin{array}{l}\text { Vitamin C } \\
\mathrm{mg} / 100 \mathrm{ml} \\
\end{array}$ \\
\hline $\begin{array}{l}\text { Sheep drinking } \\
\text { Fresh tap water }\end{array}$ & $\begin{array}{c}\bar{X} \pm \mathrm{SD} \\
\mathrm{Min}-\mathbf{M a x}\end{array}$ & $\begin{array}{c}3.22 \pm 0.0 .25 \\
2.85-3.73 \\
\end{array}$ & $\begin{array}{c}68.34 \pm 2.47 \\
61.76-73.52 \\
\end{array}$ & $\begin{array}{l}3.15 \pm 0.22 \\
2.88-3.79 \\
\end{array}$ & $\begin{array}{c}18.12 \pm 0.63 \\
15.82-21.74\end{array}$ \\
\hline $\begin{array}{l}\text { Sheep drinking } \\
\text { polluted water }\end{array}$ & $\begin{array}{c}\overline{\mathrm{X}} \pm \mathrm{SD} \\
\mathbf{M i n}-\mathbf{M a x}\end{array}$ & $\begin{array}{c}1.36 \pm 0.11 * * \\
1.07-1.79\end{array}$ & $\begin{array}{c}35.62 \pm 1.33 * * \\
31.18-40.63\end{array}$ & $\begin{array}{c}1.87 \pm 0.08 * * \\
1.52-1.98\end{array}$ & $\begin{array}{c}11.33 \pm 0.42 * * \\
9.26-13.72\end{array}$ \\
\hline
\end{tabular}

*** High significant $(\mathbf{P} \leq \mathbf{0 . 0 1})$ 
Table (4): Blood serum levels of antioxidant vitamins in goats drinking from fresh tap water and those drinking from polluted canal water

\begin{tabular}{|c|c|c|c|c|c|}
\hline Animals & Statistics & $\begin{array}{c}\text { Beta-carotene } \\
\text { mg/ } 100 \text { ml }\end{array}$ & $\begin{array}{l}\text { Vitamin A } \\
\mu \mathrm{g} / 100 \mathrm{ml}\end{array}$ & $\begin{array}{l}\text { Vitamin } E \\
\mu \mathrm{g} / 100 \mathrm{ml}\end{array}$ & $\begin{array}{l}\text { Vitamin C } \\
\mathrm{mg} / \mathbf{1 0 0} \mathrm{ml}\end{array}$ \\
\hline $\begin{array}{c}\text { Goats drinking Fresh } \\
\text { tap Water }\end{array}$ & $\begin{array}{c}\bar{X} \pm \mathrm{SD} \\
\mathrm{Min}-\mathbf{M a x}\end{array}$ & $\begin{array}{l}2.93 \pm 0.06 \\
2.69-3.14 \\
\end{array}$ & $\begin{array}{c}69.87 \pm 1.34 \\
65.83-73.22 \\
\end{array}$ & $\begin{array}{l}3.48 \pm 0.52 \\
2.61-3.89 \\
\end{array}$ & $\begin{array}{c}19.82 \pm 0.71 \\
16.76-23.92 \\
\end{array}$ \\
\hline $\begin{array}{l}\text { Goats drinking } \\
\text { polluted water }\end{array}$ & $\begin{array}{c}\bar{X} \pm \mathrm{SD} \\
\mathrm{Min}-\mathbf{M a x} \\
\end{array}$ & $\begin{array}{c}1.27 \pm 0.08 * * \\
1.03-1.52 \\
\end{array}$ & $\begin{array}{c}32.47 \pm 3.11 * * \\
27.94-38.46 \\
\end{array}$ & $\begin{array}{c}1.63 \pm 0.04 * * \\
1.32-1.87 \\
\end{array}$ & $\begin{array}{c}10.67 \pm 0.51 * * \\
8.22-12.93 \\
\end{array}$ \\
\hline
\end{tabular}

** High significant $(\mathbf{P}<0.01)$

\section{DISCUSSION:}

The essential and primary purpose of water supply programs is to deliver potable water which must be safe, adequate and accessible for man and animals. However in developing countries these aims are rarely attained. Drainage canals specially irrigation ones are still the sources of drinking water for animals in some Egyptian villages in spite of the high levels of pollution especially heavy metals. Data of this investigation proved that the improper disposal of untreated sewage waste water affected the health performance of both sheep and goats drinking from this polluted water.

Disturbance in health status of these animals (table 1) in the form of emaciation, dullness, debility and other anaemic changes especially pale mucous membranes could be attributed to the toxic effect of heavy metals specially lead and cadmium. These findings are in agreement with El-Marazky (1988) and Raghib et al., (2003) who recorded similar results.

\section{Heavy metals in drinking water of sheep and goats:}

Table (2) revealed that the mean concentration of lead, cadmium, copper and zinc in fresh tap water and polluted canal water were 0.228 , 0.004, 0.679, 2.845 ppm and 2.386, 0.637, 5.260, $9.289 \mathrm{ppm}$ respectively. Although the concentrations of these metals in fresh tap water lie within the permissible limits recommended by WHO (1984), yet the concentrations of these metals in polluted canal water were considered highly significant increased than those of fresh tap water and highly elevated than the recommended values by WHO (1984). Nearly similar findings were obtained by Zaki $e t$ al.(1994) and Abd El-Nasser et al. (1996) in water samples collected from Assiut Governorate, and by Youssef and Haleem (1999) in water samples collected from Giza, Egypt.

It can be concluded that the water of investigated canals was highly polluted with lead, cadmium, copper and zinc. These heavy metals reach the water directly from untreated sewage waste water which discharged into these irrigation canals.

\section{Blood serum antioxidant vitamins :}

Besides the clinical manifestations, the effect of this heavy metal pollution on the animal health was also clearly manifested by decreased levels of the blood serum antioxidant vitamins as shown in tables 3 and 4, there was a highly significant decrease $(P<0.01)$ in the levels of these vitamins in the serum of both sheep and goats drinking from the water of polluted canals when compared with those drinking from fresh tap water. These findings concerning Beta carotene in the serum of sheep drinking from the polluted canal water were $1.36 \pm 0.11 \mathrm{mg} / 100$ 
$\mathrm{ml}$, while those of goats were $1.27 \pm 0.08 \mathrm{mg} / 100$

ml. Meanwhile, vitamin A findings were 35.62 \pm 1.33 and $32.47 \pm 3.11 \mu \mathrm{g} / 100 \mathrm{ml}$ in both sheep and goats drinking polluted water, respectively. Sheep and goats drinking from fresh tap water recorded Beta carotene in a concentration of $3.22 \pm 0.25$ and $2.93 \pm 0.06$ $\mathrm{mg} / 100 \mathrm{ml}$ respectively and vitamin $\mathrm{A}$ as $68.34 \pm 2.47$ and $69.87 \pm 1.34 \mu \mathrm{g} / 100 \mathrm{ml}$ respectively.

The sharp decrease in the levels of vitamin $A$ as well as Beta carotene in the blood serum of sheep and goats drinking from polluted water could be attributed to the utilization of these vitamins as a defense mechanisms against the toxic effect of heavy metals present in the polluted water in a trail to help sheep and goats to maintain their immune response (Muneer $e t$ al., 1988 and Kaneko et al., 1997). Kaldrumidou et al. (1994) attributed the reduction in blood serum vitamin $A$ and beta carotene in sheep exposed to lead poisoning, to advanced degenerative changes in both kupffer and hepatic cells as the liver which is the site of vitamin A storage can be directly affected.

Results is tables ( $3 \& 4$ ) revealed that blood serum vitamin $E$ were significantly decreased ( $P$ $<0.01$ ) in sheep and goats drinking from polluted water with sewage when compared with those drinking from fresh tap water. Levels of vitamin $E$ in blood serum of sheep and goats drinking polluted water were $1.87 \pm 0.08$ and $1.63 \pm 0.04 \mu \mathrm{g} / 100 \mathrm{ml}$ respectively. While in sheep and goats drinking fresh tap water, levels were $3.15 \pm 0.22$ and $3.48 \pm 0.52 \mu \mathrm{g} / 100 \mathrm{ml}$ respectively. Such reduction in vitamin $E$ was explained by Oberly et al. (1995), which declared that chronic lead poisoning affect the immuno histochemical localization of glutathione S-transferase isoenzymes. Halliwell and Gutterridge (1985); Bendich (1987) and Tengerdy (1990) explained this reduction as the vitamin $E$ is responsible for immune enhancement as it enhances humoral immune response, so it can be utilized as a defense mechanism against the toxic effect of heavy metals.

Highly significant decrease $(P<0.01)$ was found in the level of vitamin $C$ in sheep and goats drinking from polluted water (tables 3 and 4). The levels of vitamin $C$ is blood serum of sheep and goats drinking from polluted water were $11.33 \pm 0.42$ and $10.67 \pm 0.51 \mathrm{mg} / 100 \mathrm{ml}$ respectively. Meanwhile the levels of vitamin C in blood serum of sheep and goats drinking fresh tap water were $18.12 \pm 0.63$ and $19.82 \pm$ $0.71 \mathrm{mg} / 100 \mathrm{ml}$ respectively. The reduction in blood vitamin $C$ levels of sheep and goats drinking polluted water was explained by Hornig et al. (1984) who reported that vitamin $\mathrm{C}$ enters into the defensive mechanism and has a detoxification action in the animal body, as any disease status or poison has a great effect on its function. Anderson (1982); Panush and Delafuents (1985) and Aderianne (1987) explained that vitamin $C$ was responsible for improving immunocharging capacities especially as a powerful antioxidant agent.

Recently, studies in vitro and in laboratory animals and occupationally exposed workers suggest that at least some lead induced damage may occur as a consequence of the propensity of lead to disturb the delicate proxidant and antioxidant balance that exists in mammalian cells (Monteriro et al., 1985; Lima-Hermes et al., 1991; Donaldson et al., 1993; and Basaran and Undeger, 1999).

\section{CONCLUSION:}

From the present study, it could be concluded that heavy meals pollution problems in the studied water canals were serious as reflected by the high concentrations of lead, cadmium, copper and zinc in the collected water 
samples. Also health conditions of sheep and goats drinking from this water was clearly lowered when compared with those drinking from fresh tap water. Heavy metals in polluted water have a great reflection on the blood serum levels of the studied antioxidant vitamins in sheep and goats drinking from this polluted water.

Therefore the preventive measures intended for minimizing the pollution of water with such metals are of significant concern. Hygienic disposal of sewage waste water and education of owners of sheep and goats about the risk of such pollutants should be applied.

\section{REFERENCES:}

Abdel-Nasser, M.; Shaban, A.A.; Ali, S.M.A. and Manal, M. Sayed (1996): Lead, copper, Mercury and Cadmium levels in River Nile waters at some Assiut Regions, Egypt. Assiut Vet. Med. J.; 34 (68): 95-94.

Aderianne, B. (1987): The role of antioxidant vitamins on immune function. Tech. Symposium, Daytond, Florida USA 101125.

Anderson R. (1982): Ascorbic acid and immune functions: Mechanism of immunostimulation. In Counsell, J.N. and Hornigo (eds.) "Vitamin C (Ascorbic Acid)". London: Applied Science, pp. 249-272.

APHA (American Public Health Association) (1995): Standard methods for the examination of water and waste water $19^{\text {th }}$ Ed. Washington. D.C. USA.

Basaran, N. and Undeger u. (1999) : Alterations in immune biomarkers of workers occupationally exposed to lead. The $4^{\text {th }}$ congress of toxicology in developing countries, November 6-10 antakyaTurkey.
Bendich, A. (1987): role of antioxidant vitamins on immune function. In Symposium Proceedings. "The role of vitamins on animal performance and immune response'. Technical Symposium Animal Health and nutrition. Hoffmann-LaRoche Inc. Florida, PP. 17-33.

Blumenthal U.J.; Cifuentes E. Bennet S.; Quigley M. and Ruiz Palacios G. (2001): The risk of enteric infections associated with wastewater reuse: The effect of season and degree of storage of wastewater. Transaction of Royal Society of Tropical Medicine and Hygiene; 96: 131-137.

Carr, F.H. and Price, E.A. (1926): Colorimetric determination of serum vitamin $A$ and Bata carotene. Biochem. J. 20: 4, 98.

Clark, R.B. (1989) : Marine pollution, oxford science publications, $2^{\text {nd }}$ ed. Clarendon Press, Oxford. Chap. 5, pp. 103-105.

Chew, B.P. (1987): Vitamin A and Beta Carotene on host defense. J. Dairy Sci. 70: 2732 - 2743.

Cummins, K.A., and Brunner, C.J. (1991): Effect of calf housing on plasma ascorbate and endocrine and immune function. J. Dairy Sci. 74, 1582-1588.

Dean R.B. and Suess M.J. (1985): The risk to health of chemicals in sewage applied to land. Wast Management Res. 3: 251: 278.

Dean, J.H.; Murray, M.J. and Ward, E.C. (1986): Toxic responses of the immune system. In Casarett and Doull's toxicology. Ed by C.D. Klaasen M.O. Amdur and J. Doull, pp. 275-285.

Donaldson, W.E. and Knowles, S.O. (1993) : Is lead toxicosis a reflection of altered fatty acid composition of membranes. Comparative Biochemistry and Physiology; 104 : 377-379. 
El-Marazky M.K. (1988): Studies on faecal pollution indicators. Ph.D. Thesis, Faculty of Agriculture, Cairo University.

Fenster, R. and Weiser, H. (1994): Vitamin C., Application and Recent Advances. Zootecnica International 17(8): 42-49.

Gilbert, M.W. (1997): Vitamins and the immune response of farm animals. In: "Vitamins basics" by Hoffmann-La Roche, Ltd Basel, Switzerland, New York, USA, pp. 17-33.

Goel P.K. (1997): Water Pollution (causes, effects and control) published by H.s. Poplai, New Delhi India.

Halliwell, B. and Gutterridge, J.M.C. (1985): Free radicals and toxicology. In $B$. Halliwell and J.M.C. Gutteridge, (eds). "Free radicals in biology and medicine" Oxford: Clarendon Press, PP. 206-245.

Hawks, P.R.; Oser, B.L. and Summerson, W.H. (1954): Determination of vitamin $E$ in practical physiological chemistry McGraw-Hill. Book Comp. New York. Pp. 1272-1275.

Hornig, D.; Glatthaar, B and Moser, U. (1984): General aspects of ascorbic acid function and metabolism in "Ascorbic acid in domestic animals" Ed. Wegger, I.; Tagwerker, F.J. and Moustgaard, J. The Royal Danish Agricultural Soc. Copenhagen.

Joan, S.V.; Christopher, S.F.; Arther, G. and Joel, F.L. (1995): Active oxygen In Biochemistry. Blsckle Academic and Professional pp. 313-335.

Kaldrumidou, E.; Poluzopolou, Z.; Papaioannou, N.; Tosangaras, T. and Papasteriades, A. (1994): Subclinical lead poisoning in Sheep: Ultra-strcutural study of the lesions in the liver and Kidney. Bulletin of the Hellenic
Veterimary Medical Society, 45(4):283290.

Kaneko, J.J.; Harvey, J.W. and Bruss, M.L. (1997): Clinical Biochemistry of Domestic Animals. Eds $5^{\text {th }}$ Ed. Academic Press, London. pp. 117-138.

Kegley, E.; Susan, M. and Andrews, J. (1998): The chemistry of water University Science Books Press Library of congress.

Koller, L.D. (1979): Effects of environmental contamination on the immune system. Adv. Vet. Sci. Comp. Med.; 23: 267-292.

Lake D.L. Kirk P.W.W. and Leser J.N. (1984): Fractionation characterization and speciation of heavy metals in sewage sludge-amended soils: a review. J. Environ. Qual. 13: 175-183.

Lima-Hermes, M.; Pereira, B. and Bechera, E.J.H. (1991): Are free radical involved in lead poisoning. Xenobiotica; 21 : 1085 1090.

Lowery, O.H.; Lopez, J.a. and Bessey, O.A. (1945): Determination of vitamin C. J. Biolo. Chem. 60-: 609-613.

Lynch, M.S.; Stephan, F.A. and Clark, A. (1999): Antioxidants and free radicals mechanisms in vivo. Early Hum. Dev., 56(2): 39-43.

Macpherson, A. (1994): Selenium, vitamin E and biological oxidation. In "Recent Advances in Animal Nutrition" In Coles, D.J. and Garnsworthy, P.J. (Eds): Butter worth and Heinemann's Oxford. PP. 333.

Monteriro H.P.; Abdalla D.S.; Arun, A.S and Bechers, E.J.H. (1985): Oxygen toxicity related to exposure to lead. Clinical Chemistry.; 31: 1673-1678.

Muneer, M.A.; Farah, I.O.; New Man, J.A. and Goyal, S.H. (1988): Immunosupression in animals. Br. Vit. J. 144, 288-301. 
Oberly, T.D.; Friedman, A.L.; Moser, R. and Sigal, F.L. (1995): Effects of lead administration on developing rat kidney II Functional morphologic and immunohistochemical studies. Toxical. Applied Pharmacol. 131 (1): 94-107.

Omer A.A.M.; Ibrahim M.S.; El-Haddad A.A. and Ali M.H.M. (2004): Environmental consequences of the improper land application of sewage wastewater disposal, Sohag, Egypt: soil and Groundwater pollution. The Sec. Int. Conf. For Develop and the Envir. In the Arab World, March 23-25, Assiut, Egypt.

Panush, R.S. and Delafuents, J.c. (1985):

Vitamins and immunocompetence. In Bourne, G.H. (ed.), "World Nutritional Determinates". Basel: Karger PP. 97-133.

Pugh, D.G. (2002): "Sheep and Goats Medicine" $1^{\text {st }}$ Ed. W.B. Saunder company.

Raghib, M.F.; Nassif, M.N.; Nasser, M.H.; ElKhodary S.A. and Said, E.M. (2003): Effect of some heavy metals contents on general health and blood constituents of sheep. Kafr El-Sheikh Vet. Med. J. Vol. No. 1 pp. 383-394.

Rammel, C.G. (1983): Vitamin E status of cattle and sheep N.Z. Vet. J. 31: 179.

Rock, C.L.; Jacob, R.A. and Bowen, P.W. (1996): Update on the biological characteristic of the antioxidant micronutrients "vitamin C, vitamin $\mathrm{E}$ and the carotenoids. J. Am. Diet. Ass. ; 96 (7) : 32-38.
Selvin, W. (1996): Statistical analysis of epidemiological data $2^{\text {nd }}$ Ed. Oxford University PP. 44-78.

Stephen, G.D.; Francis, A.K.; Delafunta, A. and Cyntlia, H.W. (1989): Serum vitamin E and blood glutathione peroxidase values in horses with degenerative myeloencephalopathy. Am. J. Vet. Res. 50 : 166-169.

Tengerdy, R.P. (1990): The role of vitamin E, immune response and disease resistance. Ann. N.Y. Acad. Sci. 587: 24-34.

Wheaton F. and Lawson, T. (1985) : Processing of aquatic food product. A widely interscience publication. pp.231-233, Jhon Wiley and Sous, New York, Toronto.

WHO (World Health Organization) (1984): Guide lines for drinking water quality. Geneve, No. 111.

Youssef, A.E. and Haleem, H.H. (1999): Estimation of some heavy matels in polluted and unpolluted areas and their relation to certain reproduction disorders in buffalo-cows, Beni-Suef Vet. Med. J. IX (2): 109-124.

Zaki Z.M.; Abdel-Nasser M.; Nagwa M. ElSawi and Saddek A. Sh. (1994): Toxicological elements in different water sources in Assiut Governorate and possible health risk. Bull., Fac. Sci., Assiut Univ., 23 (1-E), pp. 225-241. 
تأثير بقايا العناصر الثقيلة في المياه المستخدمة للثرب والملوثةة بالصرف الصحي على الحالة

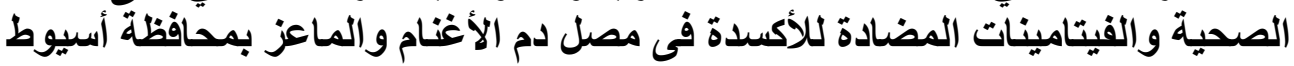

\section{عبد الر حمن أحمد على}

باحث أول بمعهر بحوث صحة الحيوان بأسيوط

أجريت هذه الاراسـة لتقدير بقايا العناصر الثقيلة فى مياه بعض القنوات المائية التى تلقى فيها مياه ومخلفات

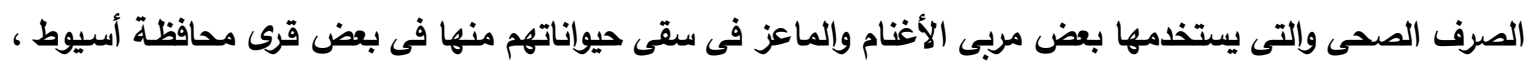

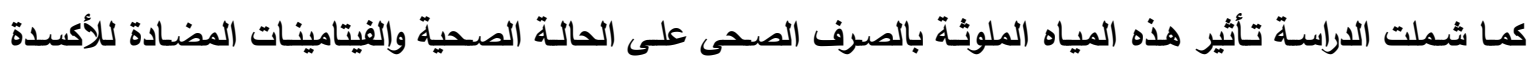

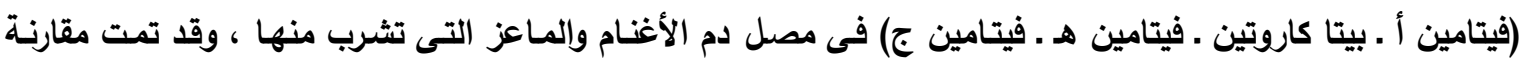

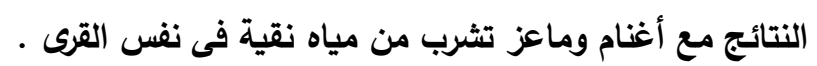

تم استخدام عدد ه 11 رأس من الأغنام من كلا الجنسين ، . 1 رأس من الماعز من كلا الجنسين تراوحت أعمارهـا

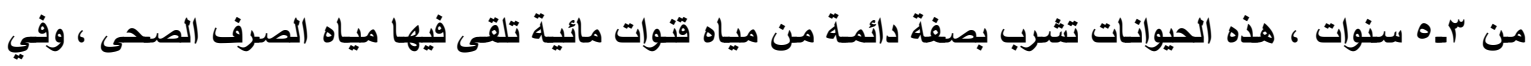

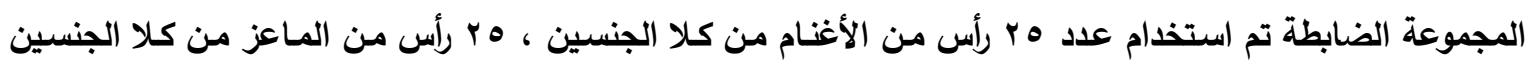

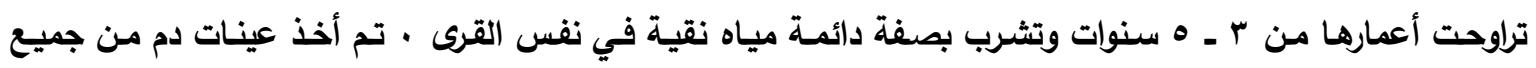

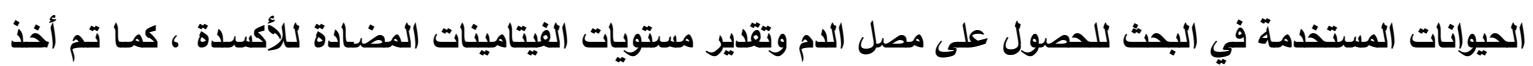

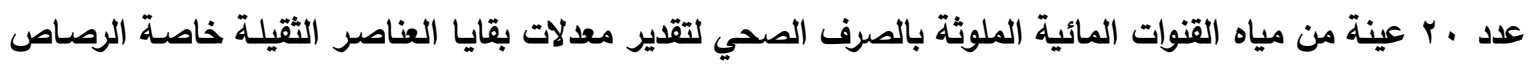

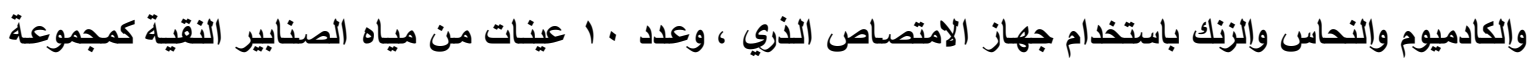

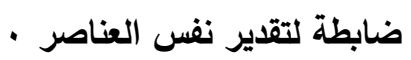

أظهرت نتائج التحليلات الكيميائية ارتفاع مستوى الرصاص والكادميوم والنحاس والزنكك فى مياه القنوات المائية

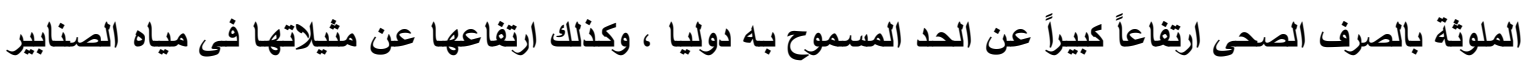

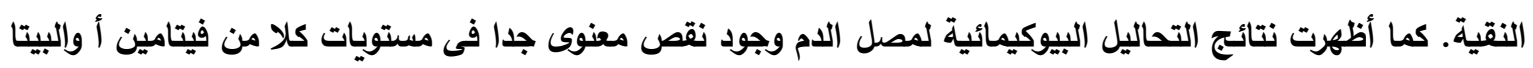

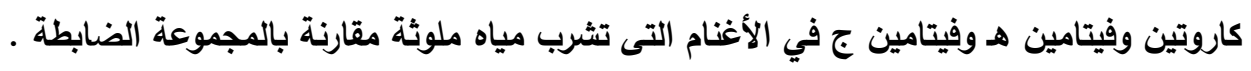

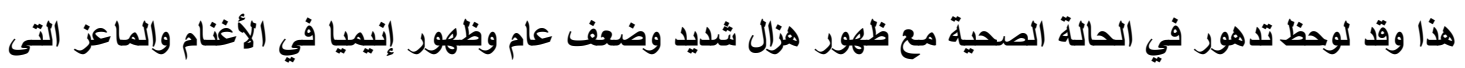
تثرب مياه ملوثة بالصرف الصحى عند مقارنتها بمثيلاتها التى تثرب مياه الصنابير النقية .

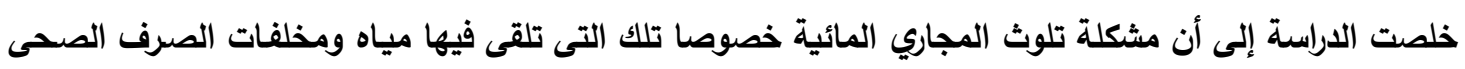

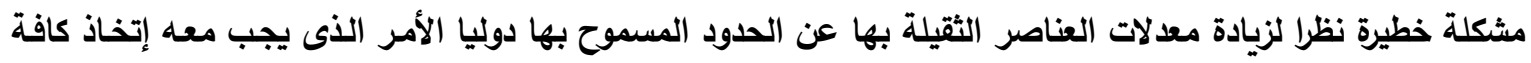

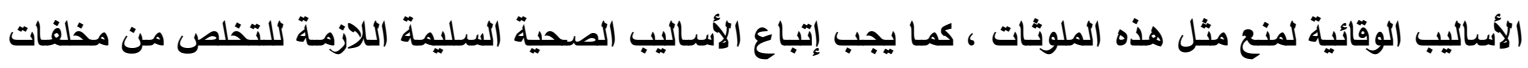

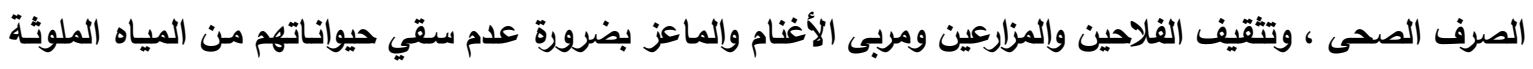
بمصادر التلوث المختلفة خاصة تلك التى تلوث بالصرف الصحي مع ضرورة سقى حيواناتهم من مصادر مياه نقية. 